\title{
A Logical Approach To The Statement Of Cash Flows
}

Fred Petro, Pepperdine University, USA

Farrell Gean, Pepperdine University, USA

\begin{abstract}
Of the three financial statements in financial reporting, the Statement of Cash Flows (SCF) is perhaps the most challenging. The most difficult aspect of the SCF is in developing an understanding of how previous transactions are finalized in this document. The purpose of this paper is to logically explain the indirect approach of cash flow whereby an understanding is established together with the mechanics of preparing the statement.
\end{abstract}

Keywords: Statement Of Cash Flows; FASB Statement No. 95; APB Opinion No. 19

\section{INTRODUCTION}

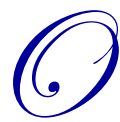

$f$ the three financial statements in financial reporting, the Statement of Cash Flows (SCF) is perhaps the most challenging. The most difficult aspect of the SCF is in developing an understanding of how previous transactions are finalized in this document. That is, the SCF is very much the culmination point for most all of financial accounting. A knowledge of how to prepare the document or learning the mechanics is not highly complex. With the use of a basic worksheet and matrix, (later presented), the preparation of the operating activities section, the most difficult of the three areas included in the SCF, can be completed quite easily. That is, this section can be completed, for the most part, without having full comprehension or understanding of how initial transactions finally reach the SCF

In 1971, Accounting Principles Board Opinion No. 19[Reporting Changes in Financial Position] required a third statement in financial reporting referred to as the Statement of Changes in Financial Position. This document, like the SCF, included three sections: operating activities, investing activities and financing activities, very similar to the SCF. However, the operating activities section could be prepared on either a working capital or cash approach, at the discretion of the preparer of the statement. If the company's cash position was weak, the working capital approach could be used. This allowed for manipulation of certain accounts, such as converting short term debt into long term debt, which would enhance current position. This problem was resolved with the issuance of Statement No. 95[FASB Statement of Financial Accounting Standards No. 95-Statement of Cash Flows, 1988] establishing standards for cash flow reporting requiring the statement of cash flows to complete the full set of financial statements for all business enterprises. According to Statement No. 95, there was no longer a choice of cash or working capital in the preparation of the operating activities section. Only the cash approach would be allowed. In the operating activities section, there were two methods allowed, the direct method and the indirect or reconciliation method. The direct method shows major operating cash receipts and disbursements comprising net cash flow from operating activities, while the indirect method reconciles net income on accrual basis to net income on a cash basis. The indirect method, in the operations section, very much parallels the cash approach in the earlier required Statement of Changes in Financial Position.

The purpose of this paper is to logically explain the indirect approach of cash flow whereby an understanding is established together with the mechanics of preparing the document. Transactions affecting cash are first recorded in journal form. The journal entries in conjunction with account analysis provide the understanding of the SCF. 


\section{MECHANICS IN THE PREPARATION OF THE SCF}

The SCF is comprised of three major sections: Cash flow from operating activities; Cash flow from investing activities; and Cash flow from financing activities. An explanation of the mechanics of these three sections follows.

The operating activities section includes three parts: (1) net income, (2) items affecting net income but not cash and (3) current assets and current liabilities.

(1) Net income of $\$ 58,000$ is taken from the accrual based income statement (Exhibit I) and placed as the beginning point number in the operating activities section (Exhibit II), subsection 1. All items in parts, (2) and (3), that follow will either be added to or subtracted from the net income figure in determining the final number, cash flow or cash used from operating activieites. This final number represents the converted number from net income on an accrual basis to net income on a cash basis.

(2) Items affecting net income but not cash such as depreciation, amortization and depletion are found among other operating expenses in the income statement (Exhibit I). Depreciation of $\$ 18,000$ is taken from (Exhibit I) and placed into (Exhibit II), subsection 2. These non-cash expenses are either added to or subtracted from net income. Depreciation and depletion will always be added to net income; however, amortization expense can either be an addition to or a subtraction from net income. For example, if a bond premium is being amortized, interest expense is credited in the journal transaction, which reduces expenses, thereby increasing net income without providing cash. Therefore, the amount in this transaction would be treated as a subtraction from net income. Conversely, amortization of a bond discount, whereby interest expense is debited, would be added to net income.

(3) Current assets and current liabilities are found in the balance sheet (Exhibit I). The increases and decreases in current assets and current liabilities are either added to or subtracted from net income. For example, using (Exhibit III), a supplement to (Exhibit II), all increases in current assets are subtracted from net income, all decreases in current assets are added to net income, all increases in current liabilities are added to net income and all decreases in current liabilities are subtracted from net income. Starting with accounts receivable, the increase of $\$ 6,000$ from the balance sheet Exhibit I, is placed in Exhibit II, subsection 3a as a subtraction. The inventory increase of 22,000 is treated as a subtraction in subsection $3 \mathrm{~b}$, while the $\$ 4,000$ decrease in prepaid expenses is treated as an addition in subsection 3c. The decreases of $\$, 8800$ and $\$ 600$ for accounts payable and income taxes payable respectively, are included as subtractions in subsections $3 \mathrm{e}$ and $3 \mathrm{f}$, while the increase of $\$ 1,400$ in accrued payables is included as an addition in subsection $3 \mathrm{~d}$. This completes the section on operating activities.

Upon completion of the operating activities section, the relevant items under the cash flow from investing can be established and placed under the appropriate subsections of Exhibit II. There were no sales of plant assets or investments. However, the $\$ 50,000$ purchase of plant assets is treated as a deduction in subsection 4 .

The final section of the SCF is the cash flow from financing activities. Again, the relevant items are identified and placed into the appropriate subsection. The issuances of capital stock and debt are included as additions in subsection 5. There was no purchase of treasury stock or retirement of debt; however, in viewing the retained earnings statement in Exhibit I, cash dividends of $\$ 30,000$ can be found, which is appropriately placed in subsection 5 .

The mechanics have been set forth; however, the why behind the how is yet to be presented. The discussion that follows will cover the understanding or the why behind the mechanics.

\section{UNDERSTANDING THE PREPARATION OF THE SCF}

\section{Cash Flows From Operating Activities}

Net income is the base point in the preparation of the SCF. It is important to understand that the objective in the operating activities section is to convert net income on an accrual basis to net income on a cash basis. The 
first step is to identify items that affected net income but had no affect on cash. These non-cash items include depreciation, amortization and depletion.

In the above example, there was depreciation of $\$ 18,000$, which was included in subsection 2 "Add items that affected net income but not cash." The journal entry to record the depreciation would be:

$\begin{array}{cr}\text { Depreciation expense } & 18,000 \\ \text { Accumulated depreciation } & 18,000\end{array}$

The entry shows an increase in an expense account, which would reduce income; however, there is no affect on cash. Therefore, the $\$ 18,000$ should be added back to net income in the process of converting accrualbased income to cash-based income.

The second part in the operating activities section is perhaps the most perplexing to understand. The mechanics can be easily memorized, from Exhibit III. That is, all decreases in current assets (exceptions include cash and notes receivable) and all increases in current liabilities (exceptions include dividends payable and notes payable) are added to net income in determining cash from operating activities. All increases in current assets (excetpions include cash and notes receivable) and decreases in current liabilities (exceptions include dividends payable and notes payable) are deducted from net income in determining cash from operating activities. An explanation of why these increases and decreases are added to or subtracted from net income in the conversion process of accrual-based income to cash-based income follows.

First of all, it is important to understand that all items in the conversion process have to, in some way, connect to the income statement. For example, accounts receivable connects to sales. Inventory connects to cost of goods sold. Salaries payable connects to salaries expense. Exceptions, such as dividends payable, notes receivable and notes payable have no connection to the income statement.

In the above example, Exhibit II, subsection 3, "Deduct increases in current assets," accounts receivable increased \$6,000, subsection 3a. Credit sales increase net income and accounts receivable, but do not increase cash. Collections on account decrease accounts receivable and increase cash. Therefore, if the accounts receivable balance increased by $\$ 6,000$, sales on account had to exceed cash collections on account by $\$ 6,000$. Therefore, the increase in accounts receivable should be deducted from net income in the conversion process of net income to cash.

\begin{tabular}{llll} 
Journal Entry & \multicolumn{3}{l}{ Account Analysis } \\
\hline Accounts receivable & 10,000 & Beginning accounts receivable & 30,000 \\
Sales & 10,000 & Sales on account & 10,000 \\
\cline { 3 - 4 } & & Total to account for & 40,000 \\
Cash & 4,000 & Ending accounts receivable & 36,000 \\
\cline { 3 - 4 } Accounts receivable & 4,000 & Collections on account & 4,000
\end{tabular}

A decrease in the balance of accounts receivable would be added to net income as follows:

\begin{tabular}{llll} 
Journal Entry & & Account Analysis \\
\hline Accounts receivable & 4,000 & Beginning accounts receivable & 30,000 \\
Sales & 4,000 & Sales on account & 4,000 \\
\cline { 2 - 4 } & & Total to account for & 34,000 \\
Cash & 10,000 & Ending accounts receivable & 24,000 \\
\cline { 3 - 4 } Accounts receivable & 10,000 & Collections on account & 10,000
\end{tabular}

Also, in the above example, Exhibit II, subsection 3, "Deduct increases in current assets," inventory increased by $\$ 22,000$, subsection $3 \mathrm{~b}$. The expired portion of inventory to cost of goods sold decreases net income but does not affect cash. The payment for inventory purchased increases inventory and decreases cash. Therefore, if the balance of inventory increased by $\$ 22,000$, cash purchases of inventory had to exceed the expired portion of inventory to cost of goods sold by $\$ 22,000$. Accordingly, the increase should be deducted from net income in converting net income to cash. 


\begin{tabular}{llll} 
Journal Entry & & Account Analysis \\
\hline \multirow{3}{*}{$\begin{array}{lll}\text { Inventory } \\
\text { Cash }\end{array}$} & 50,000 & Beginning inventory & 56,000 \\
& 50,000 & Cash purchases & 50,000 \\
\cline { 3 - 4 } Cost of goods sold & & Total to account for & 106,000 \\
Inventory & 28,000 & Ending inventory & 78,000 \\
\cline { 3 - 4 } & 28,000 & Cost of goods sold & 28,000
\end{tabular}

A decrease in the balance of inventory would be added to net income as follows:

\begin{tabular}{ll} 
Journal Entry & \\
\hline Inventory & 28,000 \\
Cash & 28,000 \\
& 50,000 \\
Cost of goods sold & 50,000 \\
Inventory &
\end{tabular}

Account Analysis

\begin{tabular}{ll} 
Beginning inventory & 56,000 \\
Cash purchases & 28,000 \\
\hline Total to account for & 84,000 \\
Ending inventory & 34,000 \\
\hline Cost of goods sold & 50,000
\end{tabular}

In Exhibit II, subsection 3 "Add decreases in current assets," prepaid expenses decreased by $\$ 4,000$, subsection 3c. The expiration of prepaid expenses decreases net income, but has no affect on cash. The payment for the purchase of prepaid expenses decreases cash and increases prepaid expenses. Therefore, if the balance of prepaid expenses decreases, expirations of prepaid expenses have to exceed cash payments for prepaid expenses. Accordingly, the $\$ 4,000$ decrease in prepaid expenses should be added to net income in converting net income to cash.

\begin{tabular}{llll} 
Journal Entry & \multicolumn{3}{l}{ Account Analysis } \\
\hline Prepaid expenses & 10,000 & Beginning prepaid expenses & 8,000 \\
Cash & 10,000 & Purchase of prepaid expenses & 10,000 \\
\cline { 3 - 4 } & & Total to account for & 18,000 \\
Expired prepaid expenses & 14,000 & Ending prepaid expenses & 4,000 \\
\cline { 3 - 4 } \begin{tabular}{l} 
Prepaid expenses \\
\cline { 2 - 3 }
\end{tabular} & 14,000 & Expired prepaid expenses & 14,000
\end{tabular}

A change in prepaid expenses resulting in an increase would be deducted from net income as follows:

\begin{tabular}{llll} 
Journal Entry & & Account Analysis & \\
\hline Prepaid expenses & 14,000 & Beginning prepaid expenses & 8,000 \\
Cash & 14,000 & Purchase of prepaid expenses & 14,000 \\
& & Total to account for & 22,000 \\
Expired prepaid expenses & 10,000 & Ending prepaid expenses & 12,000 \\
\begin{tabular}{l} 
Prepaid expenses \\
\cline { 2 - 3 }
\end{tabular} & 10,000 & Expired prepaid expenses & 10,000
\end{tabular}

In Exhibit II, subsection 3, "Deduct decreases in current liabilities," accounts payable decreased $\$ 8,800$. The payment for purchases of goods and services expense on account increases accounts payable but does not increase cash. The payment on account decreases accounts payable and cash. Therefore, if the balance of accounts payable decreases, payments on account have to exceed expenses incurred on account. Accordingly, the $\$ 8,800$ decrease in accounts payable should be deducted from net income in converting net income to cash.

\begin{tabular}{|c|c|c|c|}
\hline \multicolumn{2}{|l|}{ Journal Entry } & \multicolumn{2}{|l|}{ Account Analysis } \\
\hline Goods and services expense & 20,000 & Beginning accounts payable & 18,000 \\
\hline Accounts payable & 20,000 & Purchase of goods and services & 20,000 \\
\hline & & Total to account for & 38,000 \\
\hline Accounts payable & 28,800 & Ending accounts payable & 9,200 \\
\hline Cash & 28,800 & Payments on account & 28,800 \\
\hline
\end{tabular}

If the purchase of goods and services on account exceeds the payments of goods and services on account, the balance of accounts payable would increase. This increase should be added to net income in the conversion process as follows: 


\begin{tabular}{llll} 
Journal Entry & & Account Analysis \\
\hline Goods and services expense & 28,800 & Beginning accounts payable & 18,000 \\
Accounts payable & 28,800 & Purchase of goods and services & 28,800 \\
\cline { 3 - 4 } & & Total to account for & 46,800 \\
Accounts payable & 20,000 & Ending accounts payable & 26,800 \\
\cline { 3 - 4 } Cash & 20,000 & Payments on account & 20,000
\end{tabular}

In subsection 3, "Deduct decreases in current liabilities," income tax payable decreased by $\$ 600$. The accrual of income tax expense increases income tax payable and decreases net income but does not reduce cash. Payments on account reduce income tax payable and cash but have no affect on net income. Therefore, if the balance of income tax payable decreases, payments on account have to exceed accruals of income tax expense on account. Accordingly, the decrease of $\$ 600$ should be deducted from net income in converting net income to cash.

\begin{tabular}{llll} 
Journal Entry & \multicolumn{3}{l}{ Account Analysis } \\
\hline Income tax expense & 1,200 & Beginning income tax payable & 2,600 \\
Income tax payable & 1,200 & Accrual of income tax payable & 1,200 \\
\cline { 3 - 4 } & & Total to account for & 3,800 \\
Income tax payable & 1,800 & Ending income taxes payable & 2,000 \\
\cline { 3 - 4 } Cash & 1,800 & Payments on account & 1,800
\end{tabular}

If the accrual of income tax expense exceeds the payments on account, the balance of income tax payable would increase. The increase should be added to net income in converting net income to cash.

\begin{tabular}{lcll} 
Journal Entry & & Account Analysis \\
\hline Income tax expense & 1,800 & Beginning income tax payable & 2,600 \\
Income tax payable & 1,800 & Accrual of income tax payable & 1,800 \\
\cline { 2 - 4 } & & Total to account for & 4,400 \\
Income tax payable & 1,200 & Ending income tax payable & 3,200 \\
\cline { 2 - 4 } Cash & 1,200 & Payments on account & 1,200
\end{tabular}

Cash flows from operating activities resulted in "net cash flow from operating activities" of $\$ 44,000$.

\section{Cash Flows From Investing Activities}

In this section, there are essentially two types of transactions: (1) inflows resulting from the sale of property, plant and equipment or investments, and (2) outflows resulting from the acquisition of property, plant and equipment or investments.

In the SCF (worksheet), Exhibit II, subsection 4, "Add the sale of plant assets" and "Add the sale of investments", there was no activity. However, in this same subsection, "Deduct the purchase of plant assets," plant assets were purchased for $\$ 50,000$. The journal entry would be:

$$
\begin{array}{cr}
\text { Plant assets } & 50,000 \\
\text { Cash } & 50,000
\end{array}
$$

In this transaction, cash decreased by $\$ 50,000$.

Since the only transaction in this section was a cash decrease of $\$ 50,000$, cash flows from investing activities, would result in "net cash used by investing activities" of $\$ 50,000$.

\section{Cash Flows From Financing Activities}

In this section, there are essentially four types of transactions: (1) inflows resulting from the issuance of debt, including the issuance of bonds payable ; (2) inflows resulting from an increase in stockholders' equity such as the issuance of capital stock; (3) outflows resulting from transactions that reduce debt, such as the retirement of 
bonds; (4) outflows resulting from transactions that decrease stockholders' equity, such as payments for cash dividends or the buy-back of capital stock, commonly known as treasury stock.

In the SCF (worksheet), Exhibit II, subsection 5, "Add issuance of capital stock," common stock of $\$ 10,000$ was issued. The journal entry would be:

$\begin{array}{cr}\text { Cash } & 20,000 \\ \text { Common stock } & 20,000\end{array}$

Cash increased by $\$ 20,000$ in this transaction.

In subsection 5, “Add issuance of debt," bonds of $\$ 40,000$ were issued. The journal entry would be:

$\begin{array}{cr}\text { Cash } & 40,000 \\ \text { Bonds payable } & 40,000\end{array}$

Cash increased by $\$ 40,000$ in this transaction.

In subsection 5, "Deduct purchase of treasury stock," and "Deduct retirement of debt," there was no activity; however, in this same subsection, "Deduct payment of cash dividends," there was a $\$ 30,000$ payment of cash dividends. The journal entry would be:

Dividends payable 30,000

Cash $\quad 30,000$

Cash decreased by $\$ 30,000$ in this transaction.

Cash flows from financing activities resulted in "net cash flow from financing activities" of $\$ 30,000$.

Finally, the sum of the three sections, operating activities, investing activities and financing activities resulted in a net increase of $\$ 24,000$ which reconciles with the change from beginning cash in $20 \times 3$ of $\$ 14,000$ to ending cash of $\$ 38,000$ in $20 \times 4$ as presented in the balance sheet in Exhibit I.

\section{SUMMARY}

The reader should find this logical approach to preparing the indirect method statement of cash flows reasonably understandable and useful. The purpose of this paper has been to logically explain the indirect approach of cash flow whereby an understanding is established together with the mechanics of preparing the document. The advantages of this approach include: (1) an acceptable means to logically and analytically understand the statement of cash flows; (2) a manageable level of retention; and (3) eliminating the reliance on cumbersome worksheets which add confusion and complexity to completing the statement of cash flows.

An analysis, completed from a brief to an extended time period, can provide useful insight into firm operations. However, by separating cash flow from operations and income from operations, a new dimension of the firm is added. Cash flows from investing and financing acivities add even more to the final analysis of the business, well beyond the solely required balance sheet and income statement in financial reporting.

While our focus has been on the indirect method for converting net income to cash from operations, there is evidence that the FASB could require the direct method in the future. Perhaps the one account when converting from accrual to cash that would be better understood using the direct method would be the cost of goods sold account. Under the indirect method, it is necessary to consider changes in both the inventory account and the accounts payable to vendors account to understand what cost of goods sold would be on a cash basis. It is not explicitly expressed under the indirect method. 
If we stay with the three prong approach as endorsed by FAS 95, there are two issues that need additional research. First, consider the purchase and sale of equity and debt instruments as investment activities. It seems logical that the dividends and interest payments received while holding these securities should also be considered cash flows from investing activities. This would require another adjustment under the indirect method involving a deduction from net income and reclassifying it as an inflow of cash within the investing activities category. Second, FAS 95 currently leaves interest expense in the operating activities category. Similar to dividends being a return to stockholders, interest is a return to the creditors, and therefore it seems that interest expense would be more appropriately classified as financing activity along with dividends. The authors intend to pursue research addressing these two issues.

\section{AUTHOR INFORMATION}

Fred Petro, PhD, CMA is a Professor of Accounting at Pepperdine University in Malibu, California. Email: fpetro@pepperdine.edu

Farrell Gean Ph.D, MBA, CPA, CMA is an Associate Professor of Accounting at Pepperdine University in Malibu, California. He has been awarded the Charles Luckman Distinguished Professor title in recognition of his excellence in teaching. Email: farrell.gean@pepperdine.edu

\section{REFERENCES}

1. Accounting Principles Board Opinion No. 19, (1971), "Reporting Changes in Financial Position," Opinion No. 19 (AICPA, 1971).

2. American Accounting Association: Accounting Horizons Vol.27 No. 32013 pp. 539-578, DOI: 10.2308/acch50498

3. Collins, Stephen J., (1995), “An Effective Method for Teaching the Statement of Changes in Financial Position," Issues in Accounting Education (American Accounting Association), (Fall, 1985): 145-156.

4. FASB Could Require Direct Cash Flow Statement: Retrieved on 5/13/14 from http://www.nacubo.org/Business and Policy Areas/Accounting/Accounting_News/ FASB Could Require Direct Method Cash Flow Statement.html

5. Financial Accounting Standards Board Statement No. 95, (1988), "Statement of Cash Flows," Statement No. 95 (FASB 1988).

6. Horngren, Charles T., and Gary L. Sundem (1987), Introduction to Financial Accounting, (Prentice Hall, Inc., 1987).

7. IFRS Website- IFRS Interpretations Committee Agenda Decision May 14, 2013. Retrieved on 5/13/14 from http://www.ifrs.org/Current-Projects/IASB-Projects/IAS-7-Statement-Cash-Flows/Pages/IAS-7-Statement-CashFlows.aspx

8. Karph, Shmulik: Netflix Might Be Twisting Its Cash Flow Statement: August 18, 2013. Retrieved on 5/13/14 from http://seekingalpha.com/article/1642102-netflix-might-be-twisting-its-cash-flow-statement

9. Ketz, Edward J., and James A. Largay III (1985), "Teaching the "Funds" Statement Under Alternative Valuation Methods," Issues in Accounting Education (American Accounting Association), (Fall, 1985): 87-96.

10. Needles, Belverd E., (1989), Financial Accounting, (Houghton Miflin, Inc., 1989).

11. Paru, Jason M. Amercian Bankruptcy Institute Journal, v30.10 (Dec 2011/Jan 2012) 38-29, 60-61.

12. Pearl, Daniel (1986), "Teaching the Statement of Changes in Financial Position Without Worksheets or TAccounts," Issues in Accounting Education (American Accounting Association), (Spring, 1986): 132-140.

13. Petro, Fred A and Sherman Lawrence F (1990), "Understanding the Statement of Cash Flow for the Business Appraiser, “Valuation (January, 1990): 90-99

14. Siegel, Marc A: "Accounting Shenanigans on the Cash Flow Statement: Metrics Might Change, but Corporate Behavior Does Not." The CPA Journal. http://www.nysscpa.org/printversions/cpaj/2006/306/p38.htm

15. Walgenbach, Paul H., Ernest I. Hanson, and Norman E. Ditrich (1987), Principles of Accounting, (Harcourt Brace Jovanovich, Inc. 1987). 


\section{EXHIBIT I:}

STANDARD COMPANY

Income Statement and Statement of Retained Earnings for the year ended December 31, 20x4

Sales

Cost of goods sold

Gross Profit

Wages Expense

Depreciation Expense

Other Operating Expense

Income Tax Expense

Net Income

Beginning retained earnings

Cash dividends

Ending retained earnings
$\$ 560,000$

360,000

200,000

$\$ 84,000$

18,000

32,000

10,000

142,000

$\$ 58,000$

72,000

30,000

$\$ 100,000$

STANDARD COMPANY

Comparative Balance Sheets

December 31, 20x4

Cash

Accounts Receivable (net) Inventory

Prepaid Expenses

Plant Assets

Accumulated Depreciation

Total Assets

Accounts Payable

Accrued Liabilities

Income Tax Payable

Bonds Payable

Common Stock

Retained Earnings

Total liabilities and

Stockholders' Equity

\begin{tabular}{ccl}
$\mathbf{2 0 x 4}$ & $\mathbf{2 0 x 3}$ & $\begin{array}{l}\text { Increase } \\
(\text { decrease })\end{array}$ \\
\hline$\$ 38,000$ & $\$ 14,000$ & 24,000 \\
36,000 & 30,000 & 6,000 \\
78,000 & 56,000 & 22,000 \\
4,000 & 8,000 & $(4,000)$ \\
200,000 & 150,000 & 50,000 \\
$(60,000)$ & $(42,000)$ & 18,000 \\
$\$ 296,000$ & $\$ 216,000$ & \\
& & \\
$\$ 9,200$ & $\$ 18,000$ & $(8,800)$ \\
4,800 & 3,400 & 1,400 \\
2,000 & 2,600 & $(600)$ \\
40,000 & & 40,000 \\
140,000 & 120,000 & 20,000 \\
100,000 & 72,000 & 28,000 \\
$\$ 296,000$ & &
\end{tabular}


EXHIBIT II

STATEMENT OF CASH FLOWS

(Worksheet)

Cash Flow From Operating Activities:

1. Net Income (loss)

$\$ 58,000$

2. Items Affecting Net Income But Not Cash:

Add: Depreciation

18,000

Add: Amortization

Add: Losses

Deduct: Gains

3. Current Assets \& Current Liabilities:

Add: Decreases in current assets

Deduct: Increases in current assets

Add: Increases in current liabilities

Add: Decrease in current liabilities

a. Deduct: Increase in accounts receivable

b. Deduct: Increase in inventory

c. Add: Decrease in prepaid expenses.

d. Add: Increase in_accrued liabilities ................................................,400

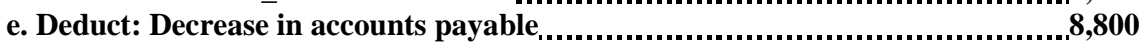

f. Deduct: Decrease in taxes payable.

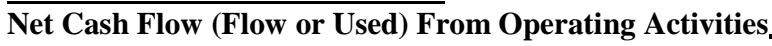

4. Cash Flows From Investing Activities:

Add: Sale of plant assets

Add: Sale of investments

Deduct: Purchase of plant assets

Deduct: Purchase of investments

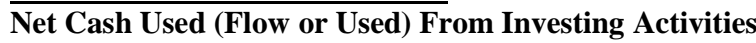

5. Cash Flows from Financing Activities:

Add: Issuance of capital stock 20,000

Add: Issuance of debt.

Deduct: Purchase of treasury stock

Deduct: Retirement of debt

Deduct: Payment of cash dividends.

Deduct: Payment of

Net Cash Flow (Flow or Used) From Financing Activities

Net Increase (Decrease) In Cash 


\begin{tabular}{lll} 
& \multicolumn{1}{c}{$\begin{array}{c}\text { EXHIBIT III } \\
\text { (Matrix) }\end{array}$} & \\
& Current Liabilities** \\
\cline { 2 - 3 } Increase & $\begin{array}{l}\text { Current Assets* } \\
\text { Deduct: the increase } \\
\text { from net income }\end{array}$ & $\begin{array}{l}\text { Add: the increase to } \\
\text { net income }\end{array}$ \\
\hline $\begin{array}{l}\text { Add: the decrease } \\
\text { to net income }\end{array}$ & $\begin{array}{l}\text { Deduct: the decrease } \\
\text { from net income }\end{array}$ \\
\hline * Except: & $\begin{array}{l}* * \text { Except } \\
\text { Notes Receivable }\end{array}$ & $\begin{array}{l}\text { Notes Payable } \\
\text { Dividends Payable }\end{array}$ \\
\hline
\end{tabular}

